\title{
Morphological and Immunohistochemical Identification of Villous $M$ Cells in the Small Intestine of Newborn Piglets
}

\author{
Identificación Morfológica e Inmunohistoquímica de los Epiteliocitos Microplegados \\ de las Vellosidades en el Intestino Delgado de Lechones Recién Nacidos
}

\author{
Li Renfeng,**; Tian Xiangqin ${ }^{* * * *}$; Qiao Songlin ${ }^{* * * * ;}$ Yang Yanyan ${ }^{* * * *}$; Zhou Enmin* \& Zhang Gaiping******
}

RENFENG, L.; XIANGQIN, T.; SONGLIN, Q.; YANYAN, Y.; ENMIN, Z. \& GAIPING, Z. Morphological and immunohistochemical identification of villous M cells in the small intestine of newborn piglets. Int. J. Morphol., 33(4):1261-1268, 2015.

SUMMARY: Microfold (M) cells act as antigen-sampling sites for initiating antigen specific mucosal immune responses, but they may also provide a gateway for enteropathogen entry. In this study we demonstrated villous M cells by morphological and immunohistochemical methods to be present in the three regions of the small intestine from newborn piglets. Immunohistochemical analysis, using anti- cytokeratin 18 (CK18) primary antibodies, showed a gradually decreased density of M cells from the lower crypt epithelium to the upper villous epithelium. The proportion of villous $\mathrm{M}$ cells was greater in the ileum than in the duodenum or the midjejunum. Ultrastructural observation revealed that villous M cells were mainly columnar in shape in the duodenum and the mid-jejunum, and appeared as more pocket-like structure in the ileum. These villous M cells exhibited short and irregular microvilli, rich vesicles and reduced glycocalyx, but lacked the lymphocyte-containing basolateral invagination. Our results support evidence that M cells can develop in the small intestinal villous epithelium of newborn piglets, implying that villous $\mathrm{M}$ cells may begin developing in the pig's small intestine during fetal stages, which depends neither on the influence of the mucosal lymphoid tissue nor the antigen from the intestinal lumen stimulation. In addition, the variable morphology and heterogeneity distribution of villous M cells in the three regions of the small intestine may be indicative of its different functional properties. This information extent our understanding of the diversity of $\mathrm{M}$ cells and provides important basic knowledge for further research on the actual role of villous $\mathrm{M}$ cells in neonate.

KEY WORDS: M Cells; Villous epithelium; Small intestine; Newborn piglets.

\section{INTRODUCTION}

M cells are specialized epithelial cells of the mucosa-associated lymphoid tissues (MALT), initially identified by electron microscopy in the rabbit appendix and human aggregated lymphoid nodules (Peyer's patches - PP) (Bockman \& Cooper, 1973; Owen \& Jones, 1974). The structure of $\mathrm{M}$ cell is quite distinct compared with the rest of the cells in the epithelium. It lack a rigid apical brush border and the basolateral side is invaginated, forming a large intraepithelial "pocket" in which immune cells such as T and B lymphocytes and macrophages reside (Knoop et al., 2009). $\mathrm{M}$ cells are able to transport luminal antigens toward the underlying immune cells that activate or inhibit the immune response, leading to either tolerance or a systemic immune response. However, due to the lack of peptide antibiotic and thick mucin layer on the M cells, some pathogens (namely
Salmonella spp., Shigella spp., reovirus type-1, poliovirus, and HIV-1) can exploit $\mathrm{M}$ cells as their portal of entry to invade the host and cause infections (Amerongen et al., 1991; Fujimura et al., 2004; Kuolee \& Chen, 2008; Takahashi et al., 2008).

M cells have been described in a variety of species, and various histochemical markers for the detection of $\mathrm{M}$ cells in light microscopy have been established. These include Ulex europaeus agglutinin-1 (UEA-1) lectin in mice (Clark et al., 1993), anti-cytokeratin 8 in rats (Rautenberg et al., 1996), anti-CK18 in pigs and bovine and anti-vimentin primary antibodies in rabbits (Gebert et al., 1992). M cells in fowl and turkey were similar in many respects to those found in mammals, including possessing a reduced number

\footnotetext{
College of Veterinary Medicine, Northwest A \& F University, Shaanxi, People's Republic of China.

* College of Veterinary Medicine, Henan Institute of Science and Technology, Xinxiang, People's Republic of China.

*** Medical Research Center, Xinxiang Medical University, Xinxiang, People's Republic of China.

***** Key Laboratory of Animal Immunology of the Ministry of Agriculture, Henan Provincial Key Laboratory of Animal Immunology, Henan Academy of Agricultural Sciences, Zhengzhou, People's Republic of China.

****** College of Animal Science and Veterinary Medicine, Henan Agricultural University, Zhengzhou, People's Republic of China.
} 
of shortened, irregular microvilli or rnicrofolds on their apical surfaces and a basolateral cytoplasmic invagination containing one or more leucocytes (Burns \& Maxwell, 1986). These observations greatly accelerate the investigation of the distribution characteristics and biological function of $\mathrm{M}$ cells.

The importance of pigs as excellent animal models has been proposed for studying the immune system (Clark et al., 2007). Some porcine enteric pathogens (namely $E$. coli, porcine epidemic diarrhea virus, porcine transmissible gastroenteritis virus) can invade porcine intestinal epithelium and replicate in the differentiated enterocytes covering the villous of the small intestine. They lead to high mortality and morbidity of porcine, especially for newborn piglets (Kim et al., 2001). Nevertheless, only little is known about how these pathogens exploit the intestinal epithelium transport pathway to breach mucosal barriers and establish local or systemic infections in different anatomical positions of newborn piglets. Therefore, it is essential to investigate the distribution characteristics of $\mathrm{M}$ cells in the small intestine of newborn piglets and their roles during the enteric pathogen invading the host.

In addition, a study has determined that the CK18 is a useful marker for detecting M-cells existing in the dome epithelium of adult porcine small intestinal PP, and directly correlates with M-cell function (Gebert et al., 1994). Another study confirms that villous $\mathrm{M}$ cells are sporadically located in the ileum epithelium of an adult pig, with columnar shape and similar to enterocytes observed by immunohistochemical methods (Chu \& Liu, 1984). Nonetheless, the detailed ultrastructure and distribution features of $\mathrm{M}$ cells in the small intestinal villous epithelium of newborn piglets remain unclear. The objective of this study was to determine the presence and distribution patterns of $\mathrm{M}$ cells in the small intestinal villous epithelium of newborn piglets at birth, by immunohistochemical and morphological methods, as well as observing of the detailed ultrastructural characteristics of these cells.

\section{MATERIAL AND METHOD}

Experimental animals. Three-way crossbred (Landrace, Large white, Duroc) newborn piglets (one day after birth) were purchased from the pig farm of Northwest Agriculture \& Forestry University. All piglets were clinically healthy and free of infection. This study was conducted in accordance with the Guidelines for the Care and Use of Animals of Northwest A \& F University. All efforts were made to minimize the number of animals used and their suffering.
Immunohistochemistry processing. Fresh small intestinal samples were removed immediately after slaughtered and snap-frozen in optimum cutting temperature (OCT) embedding compound onto cork squares by use of liquid nitrogen-cooled isopentane, and kept at $-80{ }^{\circ} \mathrm{C}$ prior to cryostat sectioning. Serial 3 to $5 \mu \mathrm{m}$ thick frozen sections were sliced on a microtome and mounted on poly-L-lysine coated slides, post-fixed with acetone for 10 minutes at -20 ${ }^{\circ} \mathrm{C}$. Before the staining protocol, all frozen tissue sections were set at room temperature for 20 min and washed with phosphate-buffered saline (PBS). Immunohistochemical staining was performed by using the avidin-biotin-peroxidase complex technique (Hsu et al., 2005). Briefly, endogenous peroxidase was blocked with $3 \%$ aqueous hydrogen peroxide solution for $15 \mathrm{~min}$ at room temperature. After being washed in PBS, sections were pretreated with $10 \%$ normal goat serum to inhibit nonspecific background staining. The slides were incubated with mouse anti-CK18 antibody (1: 1000; clone CY90 Sigma) overnight at $4{ }^{\circ} \mathrm{C}$ in a moist chamber. After being washed in PBS, sections were incubated with biotinylated goat anti-mouse IgG (diluted 1: 200; Sigma) for $40 \mathrm{~min}$. Staining was performed using the DAKO EnVision kit (GK500705) following the manufacturer's protocol. Control slides were prepared using the same method, omitting either primary or secondary antibodies. Images were captured, and the resulting images were analyzed using Image-Pro® Plus software.

Electron microscopy. For scanning electron microscopy (SEM), the duodenum, mid-jejunum and ileum fragments from newborn piglets were removed after slaughtered and fixed with $2.5 \%$ glutaraldehyde in $100 \mathrm{mM}$ sodium phosphate buffer, $\mathrm{pH} 7.4$ at $4{ }^{\circ} \mathrm{C}$ for $4 \mathrm{~h}$, followed by post-fixation with $1 \%$ osmium tetroxide for $1 \mathrm{~h}$ at room temperature and dehydrated in graded ethanol solution. Dehydrated tissues were critical point-dried with $\mathrm{CO}_{2}$ and sputter coated with platinum. Samples were viewed by using an FEI QUANTA200 scanning electron microscope (Hitachi, Japan). For transmission electron microscope (TEM), the small intestinal samples were fixed as described above for SEM, dehydrated in a graded series of ethanol and embedded in epoxy resin. Ultrathin sections, $30-40 \mathrm{~nm}$ thick, were cut with a diamond knife and mounted on nickel grids. Thereafter, the grids were stained with uranium acetate and lead citrate, and visualized under a HT- 7700 TEM (Hitachi, Japan).

Statistical analyses. The number of villous $\mathrm{M}$ cells per villus was determined statistically on the mean \pm S.E.M. of villous $\mathrm{M}$ cells numbers from 15 randomly selected villi per sample, with $n$ being the number of villous $M$ cells per villus. Data were analyzed using one-way analysis of variance (ANOVA). The results deviating from the null hypothesis at a level of $\mathrm{P}<0.05$ were accepted as significant. 


\section{RESULTS}

Identification of M-cells by CK18 antibody. Immunohistochemical staining showed that CK18-positive cells were present in the villous epithelium of three parts of the small intestine from newborn piglets. These villous $\mathrm{M}$ cells, as two different distribution forms, dense and diffuse types, were interspersed between enterocytes. The heterogeneous distribution of $\mathrm{M}$ cells within the villous epithelium was also revealed by immunohistochemical staining, as evidenced by a gradually decreased density of CK18-positive cells from lower crypt epithelium to upper villous epithelium (Fig. 1a-c).

Histomorphometric analyses showed that the ileum had significantly increased number $(\mathrm{P}<0.01)$ of villous $\mathrm{M}$ cells as compared to the values obtained from the duodenum and the mid-jejunum. The number of the $\mathrm{M}$ cells per villus $(n=12.6)$ in the ileum was increased by $61.5 \%$ and $40.0 \%$ than in the duodenum $(n=7.8)$ and mid-jejunum $(n=9)$, respectively. However, this increase was not significantly different between the duodenum and the mid-jejunum $(\mathrm{P}=$ $0.313)$. In the mid-jejunum only $15.4 \%$ increased numbers of villous $\mathrm{M}$ cells than in the duodenum was recorded (Fig. 1d).

Morphological findings. Scanning electron microscopy (SEM) revealed the villous epithelium contained darker cell interspersed with a homogeneous population of polygonal epithelial cells. These cells, with dark apical membrane, possessed markedly blunted and reduced numbers of microvilli and had a slightly depressed surface compared to neighboring villous epithelial cells (Fig. 2). The blunted microvilli formed some ridges and more typical microfolds on the apical surface. In contrast, the surface microvilli from its neighboring villous epithelial cells were more numerous and regular and had a lighter stained apical surface (Fig. 2c). SEM also showed the variable morphology of apical surface between the villous $M$ cells in different segments of the small intestine from newborn piglets (Fig. 2).

Transmission electron microscopy revealed that these villous $\mathrm{M}$ cells had no obvious lateral invaginations and no lymphocytes, lymphoblasts or macrophages were found in theintra-cells (Fig. 3). Their cytoplasm were often less electron-dense than that of the adjacent epithelial cells and appeared as attenuated pale cytoplasm (Fig. 3). In addition, the villous $M$ cells in duodenum and mid-jejunum were mostly columnar in shape similar to that of adjacent enterocytes, not having a typical pocket-like morphology (Fig. 3a-b). Unlike the morphology in duodenum and midjejunum, the ileal villous $\mathrm{M}$ cells exhibited more pocketlike structure (Fig. 3c, 3g and 3h), whose width and height were approximately equal.

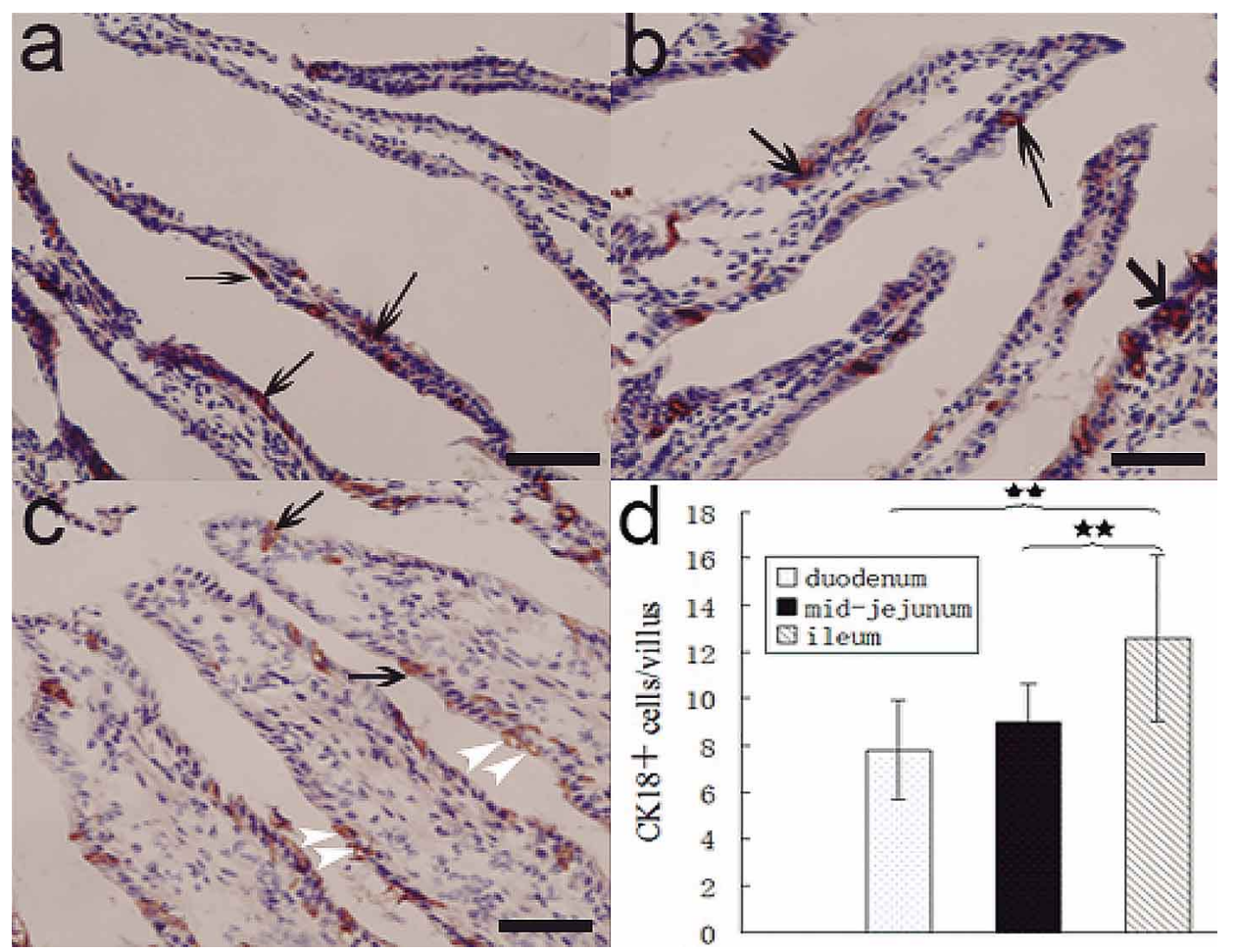

Fig.1.

CK 18 immunohistochemical staining of villous $\mathrm{M}$ cells in the small intestine of newborn piglets. a, b, c Villous M cells are viewed in the duodenum, mid- jejunum and ileum, respectively. Villous $M$ cells were found as two different distribution forms, dense (white arrowhead) and diffuse types (arrows). Magnification: x400, scale bar $80 \mu \mathrm{m}$. d Comparison of numerical values of CK18positive cells on the villous epithelium between different segments of small intestine from newborn piglets. The data represent the mean \pm S.E.M. of the number of the $M$ cells per villus observed in 15 villi per sample $(* * \mathrm{p}<0.01)$. 


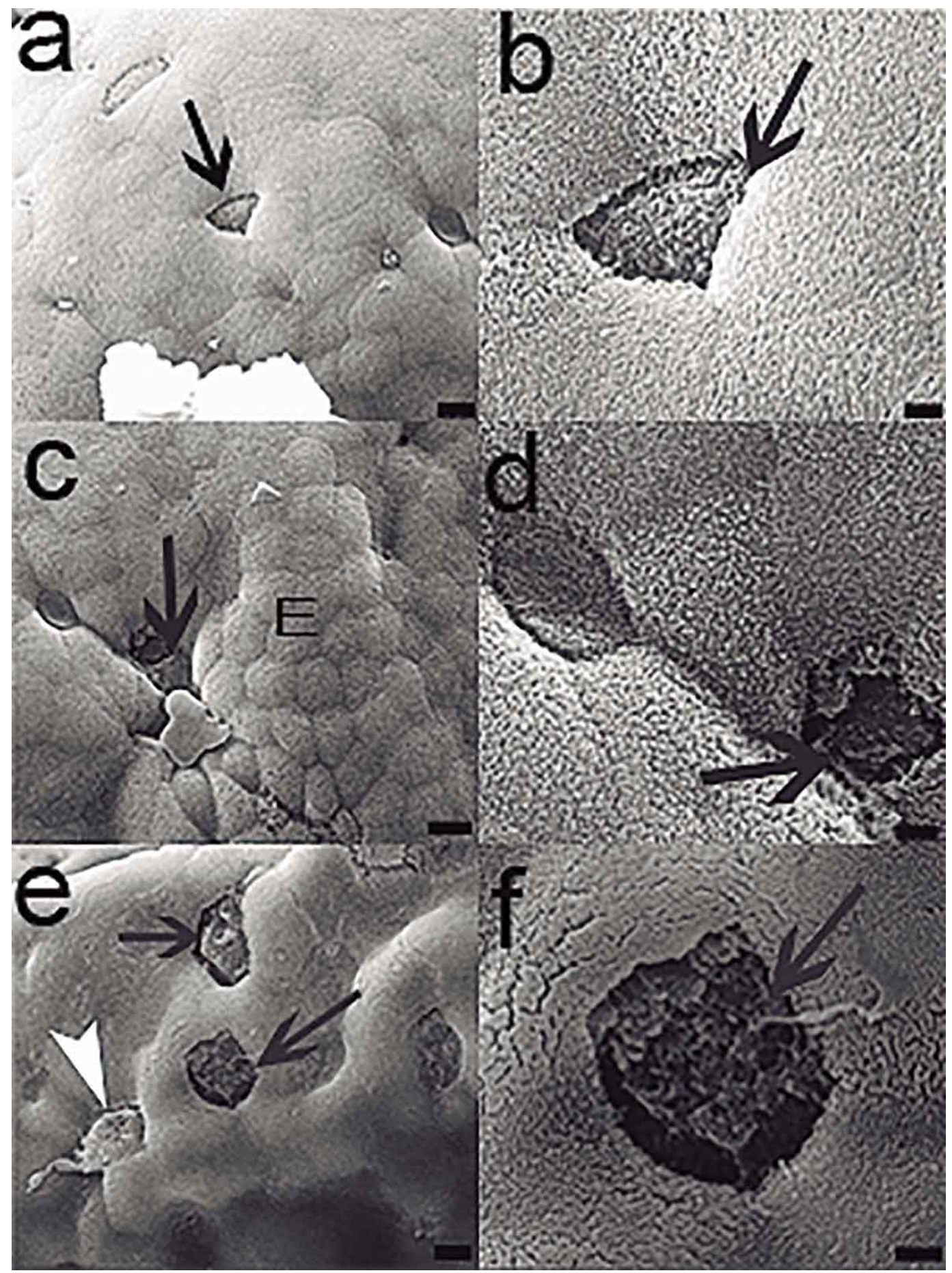

Fig. 2. Scanning electron micrograph of villous $M$ cells in the different parts of the small intestine from newborn piglets. Scanning electron micrograph shows different surface shape of villous $\mathrm{M}$ cells in different segments of the small intestine, and demonstrates that the villous $\mathrm{M}$ cells are distinguished from enterocytes (E) and goblet cells (white arrowhead) within villous epithelium by their relatively depressed apical surface, with darker and short stub-like microvilli (arrows). a, c and e represent the duodenum, mid-jejunum and ileum of the small intestine, respectively. b, $d$ and $\mathrm{f}$ represent higher magnification of a, $\mathrm{c}$ and e, respectively. The scale bar for a, $\mathrm{c}$ and e is $5 \mu \mathrm{m}$; for b, d and f 1.25 m. a, c, e magnification:x3000; b, d, f magnification: x10000. 
These villous M cells showed a reduced glycocalyx on the apical membrane and absent of an organized terminal web of microfilaments or they were scarcely visible in the apical cytoplasm (Fig. 3). Some ellipsoid nuclei were situated at the more luminal opposite portion, compared with the regular position of nuclei of other villous epithelial cells, and the nuclei were larger than in the adjacent villous epithelial cells. Further, these villous M cells were few secretory granules and lysosomes, rich mitochondria and numerous small vesicles present in the cytoplasm. All M cells were connected with the neighboring epithelial cells by junctional complexes and interdigitations (Fig. 3e).

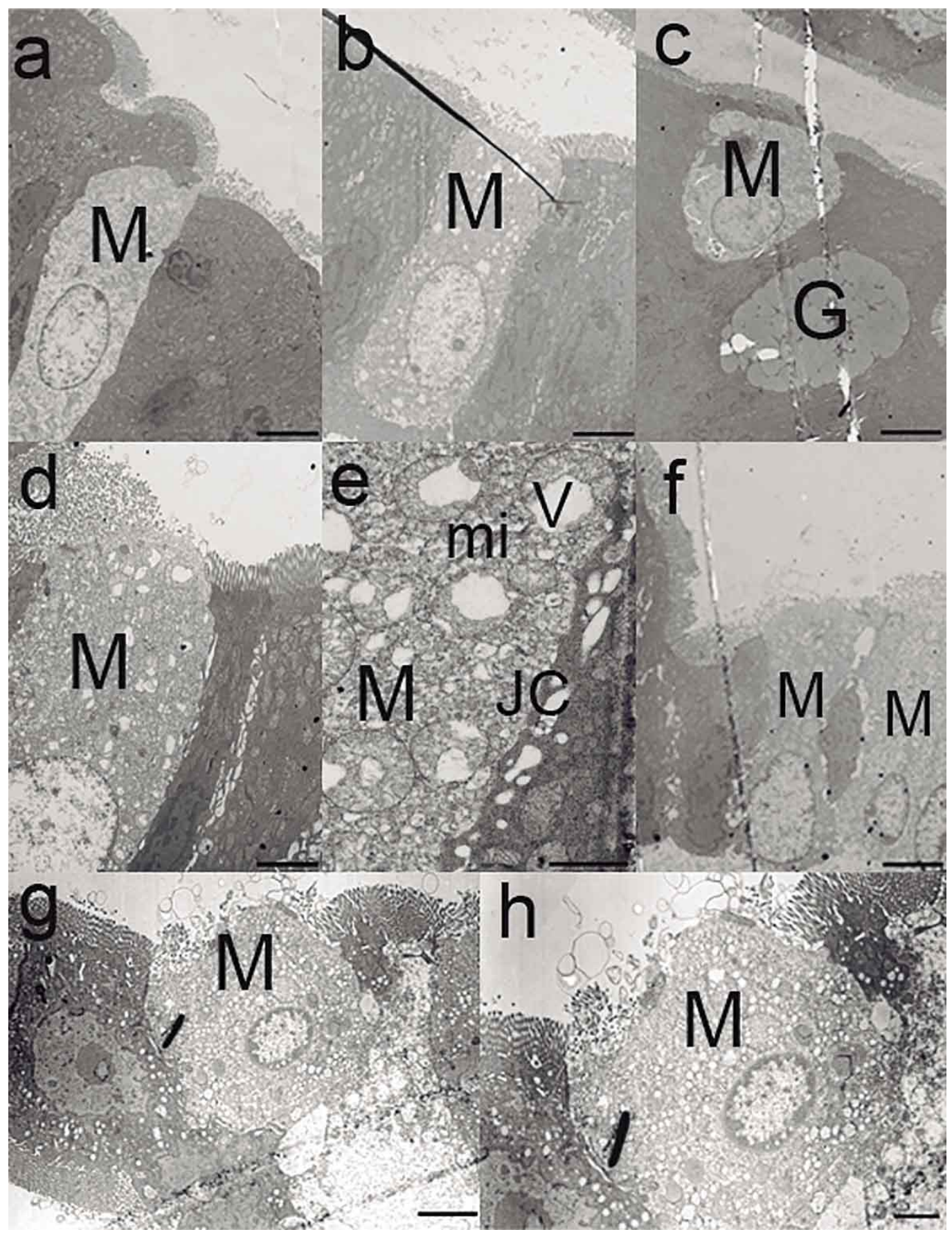

Fig. 3 Transmission electron micrograph view of villous $M$ cells in the different parts of the small intestine of newborn piglets. The apical surface of villous $M$ cell are partially concealed by neighboring enterocytes with bulging apical portions, characterized by irregular microvilli and attenuated pale cytoplasm. a, b and c represent the duodenum, mid-jejunum and ileum of the small intestine, respectively; One M cell and its neighboring goblet cell $(\mathrm{G})$ are shown in $\mathrm{c}$; $\mathrm{d}$ and e represent high magnification of villous $M$ cells within the mid-jejunum, which show the junction complex (JC) between villous $M$ cells with adjacent cells, vesicles (v) of various sizes and mitochondria (mi); Two neighboring villous $\mathrm{M}$ cells are shown in $\mathrm{f} ; \mathrm{g}$ shows the pocket-like $M$ cell in the ileal villous epithelium and $h$ is the higher magnification of g. The scale bar for $a, b$, $\mathrm{c}$ and $\mathrm{f}$ is $5 \mu \mathrm{m}$; for $\mathrm{d}$, e, $\mathrm{g}$, and $\mathrm{h}$ is $2.5 \mu \mathrm{m}, 1.0$ $\mu \mathrm{m}, 3.3 \mu \mathrm{m}$, and $1.7 \mu \mathrm{m}$, respectively. a, b, c, f magnification:x1000; d magnification:x1500; e magnification:x5000; g magnification:x3000; $\mathrm{h}$ magnification:x6000. 


\section{DISCUSSION}

M cells were previously found on the FAE overlying the dome structure of aggregated lymphoid nodules in the small intestine of humans, as well as in the colon and rectum of mouse (Miller et al., 2007), and they have been identified in a 17-week-old human fetus, the bursa of Fabricius of 15-day-old chick embryos, the ileum of a 7month-old bovine fetus, and in rats, mice and rabbits (Davis \& Owen, 1997). Further, M cells have been documented only in the FAE-associated epithelium and occasionally on villi immediately adjacent to the lymphoid follicle and dome (Gebert et al., 1994; Neutra et al., 1996). In previous studies across a range of species it was found that $\mathrm{M}$ cells exhibited similar morphology but that their location and densities were likely to be variable (Brayden et al., 2005). To the best of our knowledge, only a few studies concerning the porcine $\mathrm{M}$ cells on the dome epithelium in PP of adult pig have been published (Gebert et al., 1994; Miyazawa et al., 2006; Valpotic et al., 2010). In particular, the ultrastructural characteristics and distribution pattern of villous $M$ cells in the small intestine of newborn piglets have not been well defined. In this study we demonstrated villous $M$ cells by morphological and immunohistochemical methods to be present in the three regions of the small intestine. This observation is not in agreement with the previous report that no villous $\mathrm{M}$ cells were found in the villous epithelium not bordering on a dome of PP from porcine small intestine (Gebert et al., 1994), but provides evidence of the existence of $M$ cells in the villous epithelium away from the small intestinal $\mathrm{PP}$ of newborn piglets.

In addition, our results showed that the proportion of $\mathrm{M}$ cells was greater in the ileum than in the duodenum or mid-jejunum. Using TEM morphological differences were found between the villous $\mathrm{M}$ cells in the three regions of the small intestine. The villous $\mathrm{M}$ cells were mostly columnar in shape in the duodenum and mid-jejunum, but more pocket-like structure in the ileal. SEM revealed these $M$ cells have the typical $M$ cells features and so have a marked reduction in apical microvilli and they appear darker than the surrounding epithelial cells. In addition, the density of villous $\mathrm{M}$ cells shows a gradual decrease from the lower crypt epithelium to the upper villous epithelium. Together these findings provide evidence that $M$ cells can develop in the pig's small intestine during fetal stages, and indicate that these $\mathrm{M}$ cells may possess different migration rates from crypt to villous epithelium.

The mouse anti-cytokeratin Peptide 18 monoclonal antibody (clone CY-90) used in this study was produced from mice immunized with human epidermal carcinoma A-431 and MCF-7 human breast cancer cell lines. This antibody reacts specifically with a wide variety of simple epithelia including glandular epithelia (see product description). The use of CK18 as a positive phenotypic marker of porcine $\mathrm{M}$ cells could facilitate the resolution of some questions regarding the distribution, localization and development in the pig. However, we found some CK18 positive cells in the small intestinal glandular epithelium, a result which suggests that CK18 may not be the perfect marker for identifying porcine $\mathrm{M}$ cells in the small intestine. In fact CK18 is a constituent of the cytoskeleton in the cells of many simple epithelia, such as the epithelia of the intestine, bronchi and alveoli as well as hepatocytes. Due to its conservative properties it has been used to normalize gene expression (Bragulla \& Homberger, 2009). Previous studies have assumed that cells intensely stained by the CK18 antibodies in FAE were M-cells and that the weakly stained epithelial cells were enterocytes (Gebert et al., 1994). Our results also confirmed that porcine villous M-cells contained more CK18 than did enterocytes and glandular epithelium and we consider that CK18 is still a useful marker for the study of porcine M cells. However, its presence in other epithelial cells should be borne in mind in further any studies of porcine $\mathrm{M}$ cells.

The role of the villous $\mathrm{M}$ cells has been previously demonstrated (Jang et al., 2004) as important for antigensampling in the induction of antigen-specific immune responses to gastrointestinal environmental antigens. It is thought that the development of $\mathrm{M}$ cells is dependent on contact with lymphocytes in PP or exposure to exogenous antigen (Mach et al., 2005). However, in this study of newborn piglets which had limited contact with the environment and in the absence of intestinal lymphoid tissue still appear to have developed $\mathrm{M}$ cells and so challenges the accepted assumption. Further this finding of atypical $\mathrm{M}$ cells in newborn pigs in the absence of direct involvement with the immune system raises the possibility of an alternative function and the assumption of additional roles in the intestine. We suggest that these villous M cells may still interact with pathogens and so provide a portal for their entry into the mucosa. Bearing in mind the susceptibility of newborn pigs to infection we feel that this suggestion is worthy of further investigation.

To our knowledge, this is the first report demonstrating the presence of, intestinal villous $M$ cells in the newborn piglets, with variable morphology and distribution pattern in the different regions of the small 
intestine, as well as illustrating its detailed ultrastructural characteristics. These findings are indicative of villous $\mathrm{M}$ cells differentiating in the early stages of life, and suggesting that the function of villous M cells may vary between different anatomical positions of host. This study provides valuable new information for extending our understanding of the diversity of distribution and location of $\mathrm{M}$ cells. Much work is required to clarify the actual role of the intestinal villous $\mathrm{M}$ cells in neonate.

\section{ACKNOWLEDGMENTS}

The authors would like to thank Dr Gregson, UCLION, London University, for revising the paper and advice in the work. This work was supported by grants from China Agriculture Research System (No. CARS-36), and the Pig Industry Technology System Innovation Team Project of Henan Province (S2012-06).

RENFENG, L.; XIANGQIN, T.; SONGLIN, Q.; YANYAN, Y.; ENMIN, Z. \& GAIPING, Z. Identificación morfológica e inmunohistoquímica de los epiteliocitos microplegados de las vellosidades en el intestino delgado de lechones recién nacidos. Int. J. Morphol., 33(4):1261-1268, 2015.

RESUMEN: Los epiteliocitos microplegados (células M) actúan como receptores de antígeno para iniciar la respuesta inmune específica de las mucosas, pero también pueden proporcionar una puerta de entrada para enteropatógenos. En este estudio, se demostró por métodos morfológicos e inmunohistoquímicos que los epiteliocitos microplegados de las vellosidades están presentes en las tres regiones del intestino delgado de lechones recién nacidos. Se utilizaron anticuerpos primarios de citoqueratina 18 (CK18) para el análisis inmunohistoquímico, el cual mostró una disminución gradual de la densidad de los epiteliocitos microplegados desde el epitelio de las criptas inferiores hasta el epitelio de las vellosidades superiores. La proporción de los epiteliocitos microplegados, fue mayor en el íleon que el duodeno o yeyuno medio. La observación ultraestructural reveló que los epiteliocitos microplegados fueron principalmente de forma columnar en el duodeno y el yeyuno medio. Además, mostraron microvellosidades cortas e irregulares, muchas vesículas y glucocáliz reducidos, pero carecían de invaginaciones basolaterales contenedoras de linfocitos. Nuestros resultados apoyan la evidencia de que los epiteliocitos microplegados pueden desarrollarse en el epitelio de las vellosidades intestinales de los lechones recién nacidos, lo que implica que estas células pueden comenzar a desarrollarse en el intestino delgado del cerdo durante las etapas fetales, y no dependen ni de la influencia del tejido linfoide de las mucosas ni del antígeno para la estimulación del lumen intestinal. Además, la morfología y heterogeneidad de distribución de los epiteliocitos microplegados en las tres regiones del intestino delgado pueden ser indicativas de sus diferentes propiedades funcionales. Esta información mejora nuestra comprensión de la diversidad de los epiteliocitos microplegados y proporciona conocimientos básicos importantes para la investigación sobre el papel de los epiteliocitos microplegados en las vellosidades del neonato.

PALABRAS CLAVE: Epiteliocitos microplegados; Celulas M; Epitelio velloso; Intestino delgado; Lechones neonatos.

\section{REFERENCES}

Amerongen, H. M.; Weltzin, R.; Farnet, C. M.; Michetti, P.; Haseltine, W. A. \& Neutra, M. R. Transepithelial transport of HIV-1 by intestinal M cells: a mechanism for transmission of AIDS. J. Acquir. Immune Defic. Syndr., 4(8):760-5, 1991.

Bockman, D. E. \& Cooper, M. D. Pinocytosis by epithelium associated with lymphoid follicles in the bursa of Fabricius, appendix, and Peyer's patches. An electron microscopic study. Am. J. Anat., 136(4):455-77, 1973.

Bragulla, H. H. \& Homberger, D. G. Structure and functions of keratin proteins in simple, stratified, keratinized and cornified epithelia. J. Anat., 214(4):516-59, 2009.

Brayden, D. J.; Jepson, M. A. \& Baird, A. W. Keynote review: intestinal Peyer's patch M cells and oral vaccine targeting. Drug Discov. Today, 10(17):1145-57, 2005.

Burns, R. B. \& Maxwell, M. H. Ultrastructure of Peyer's patches in the domestic fowl and turkey. J. Anat., 147(1):235-43, 1986.
Chu, R. M. \& Liu, C. H. Morphological and functional comparisons of Peyer's patches in different parts of the swine small intestine. Vet. Immunol. Immunopathol., 6(3-4):391-403, 1984.

Clark, K. J.; Carlson, D. F. \& Fahrenkrug, S. C. Pigs taking wing with transposons and recombinases. Genome Biol., 8 (Suppl 1):S13, 2007.

Clark, M. A.; Jepson, M. A.; Simmons, N. L.; Booth, T. A. \& Hirst, B. H. Differential expression of lectin-binding sites defines mouse intestinal M-cells. J. Histochem. Cytochem., 41(11):1679-87, 1993.

Davis, I. C. \& Owen, R. L. The immunopathology of M cells. Springer Semin. Immunopathol., 18(4):421-48, 1997.

Fujimura, Y.; Takeda, M.; Ikai, H.; Haruma, K.; Akisada, T.; Harada, T. \& Ohuchi, M. The role of M cells of human nasopharyngeal lymphoid tissue in influenza virus sampling. Virchows Arch., 444(1):36-42, 2004. 
RENFENG, L.; XIANGQIN, T.; SONGLIN, Q.; YANYAN, Y.; ENMIN, Z. \& GAIPING, Z. Morphological and immunohistochemical identification of villous M cells in the small intestine of newborn piglets. Int. J. Morphol., 33(4):1261-1268, 2015.

Gebert, A.; Hach, G., \& Bartels, H. Co-localization of vimentin and cytokeratins in M-cells of rabbit gut-associated lymphoid tissue (GALT). Cell Tissue Res., 269(2):331-40, 1992.

Gebert, A.; Rothkötter, H. J. \& Pabst, R. Cytokeratin 18 is an Mcell marker in porcine Peyer's patches. Cell Tissue Res., 276(2):213-21, 1994.

Jang, M. H.; Kweon, M. N.; Iwatani, K.; Yamamoto, M.; Terahara, K.; Sasakawa, C.; Suzuki, T.; Nochi, T.; Yokota, Y.; Rennert, P. D.; Hiroi, T.; Tamagawa, H.; Iijima, H.; Kunisawa, J.; Yuki, Y. \& Kiyono, H. Intestinal villous $M$ cells: an antigen entry site in the mucosal epithelium. Proc. Natl. Acad. Sci. U. S. A., 101(16):6110-5, 2004.

Kim, S. Y.; Song, D. S. \& Park, B. K. Differential detection of transmissible gastroenteritis virus and porcine epidemic diarrhea virus by duplex RT-PCR. J. Vet. Diagn. Invest., 13(6):516-20, 2001

Knoop, K. A.; Kumar, N.; Butler, B. R.; Sakthivel, S. K.; Taylor, R. T.; Nochi, T.; Akiba, H.; Yagita, H.; Kiyono, H. \& Williams, I. R. RANKL is necessary and sufficient to initiate development of antigen-sampling $\mathrm{M}$ cells in the intestinal epithelium. $J$. Immunol., 183(9):5738-47, 2009.

Kuolee, R. \& Chen, W. M cell-targeted delivery of vaccines and therapeutics. Expert Opin. Drug Deliv., 5(6):693-702, 2008.

Mach, J.; Hshieh, T.; Hsieh, D.; Grubbs, N. \& Chervonsky, A. Development of intestinal M cells. Immunol. Rev., 206(1):177$89,2005$.

Miller, H.; Zhang, J.; Kuolee, R.; Patel, G. B. \& Chen, W. Intestinal M cells: the fallible sentinels? World J. Gastroenterol., 13(10):1477-86, 2007.

Miyazawa, K.; Aso, H.; Kanaya, T.; Kido, T.; Minashima, T.; Watanabe, K., Ohwada, S.; Kitazawa, H.; Rose, M. T.; Tahara, K.; Yamasaki, T. \& Yamaguchi, T. Apoptotic process of porcine intestinal M cells. Cell Tissue Res., 323(3):425-32, 2006.

Neutra, M. R.; Frey, A. \& Kraehenbuhl, J. P. Epithelial M cells: gateways for mucosal infection and immunization. Cell, 86(3):345-8, 1996

Owen, R. L. \& Jones, A. L. Epithelial cell specialization within human Peyer's patches: an ultrastructural study of intestinal lymphoid follicles. Gastroenterology, 66(2):189-203, 1974.

Rautenberg, K.; Cichon, C.; Heyer, G.; Demel, M. \& Schmidt, M. A. Immunocytochemical characterization of the follicleassociated epithelium of Peyer's patches: anti-cytokeratin 8 antibody (clone 4.1.18) as a molecular marker for rat $\mathrm{M}$ cells. Eur. J. Cell Biol., 71(4):363-70, 1996.

Takahashi, Y.; Misumi, S.; Muneoka, A.; Masuyama, M.; Tokado, H.; Fukuzaki, K.; Takamune, N. \& Shoji, S. Nonhuman pri- mate intestinal villous M-like cells: an effective poliovirus entry site. Biochem. Biophys. Res. Commun., 368(3):501-7, 2008.

Valpotic, H.; Kovsca Janjatovic, A.; Lackovic, G.; Bozic, F.; Dobranic, V.; Svoboda, D.; Valpotic, I. \& Popovic, M. Increased number of intestinal villous $\mathrm{M}$ cells in levamisole -pretreated weaned pigs experimentally infected with F4ac? enterotoxigenic Escherichia coli strain. Eur. J. Histochem., 54(2):e18, 2010.

\section{Correspondence to: \\ Renfeng $\mathrm{Li}$ \\ College of Veterinary Medicine \\ Northwest A \& F University \\ Shaanxi \\ PEOPLE'S REPUBLIC OF CHINA}

Email: lirenfeng@sina.com

Received: 14-05-2015

Accepted: 04-08-2015 